\title{
Porcine Circovirus: Historical Outlooks and Non-Porcine Victims
}

\section{Getnet Zemenu Adiss*}

Faculty of veterinary medicine, Departments of Virology, Gent University, Belgium

*Corresponding author: Getnet Zemenu Adiss, Gent University, Faculty of veterinary medicine, Departments of virology, Merelbeke 9820 Salisburylaan 84, Belgium, Tel: 0487297737; Email: Getnet.adiss@ugent.be

\section{Mini Review}

Volume 5 Issue 1

Received Date: January 10, 2020

Published Date: March 04, 2020

DOI: $10.23880 /$ oajvsr-16000191

\section{Abstract}

Porcine circovirus is an important viral species in the genus circovirus. It causes an immerse economic losses in the piggery industry. According to the retrospective studies, PCV2 has circulated before its acclaimed detection from samples taken as of the first outbreak in Canada. A bit far on in time, it has been reported in Europe, United States and Asian countries. The disease is endemic in most pig producing countries. Since then phylogeny studies supported for the immergence of various new Porcine circoviruses variants and genotypes. In addition to its natural reservoirs (wild and feral pigs), it also inhibits calves, goats, canines and mice. Some insects like mosquitoes are also the potential carrier of PCV2 even let it for cross species transmission. Hence those proper prevention measures of the mechanical carrier vectors of the disease should be noted together with the need of efficient vaccine against the pathogenic porcine circoviruses types.

Keywords: Porcine Circovirus; Non-Porcine Victims

\section{Introduction}

Viruses are the smallest biological agents that reproduce inside the cells of living hosts or in vitro as if having in vivo conditions [1,2]. Amongst the common family members of viruses, the circoviridae is the recognized family which makes up the smallest single stranded circular DNA based genomes. The circoviridae is classified into the two main genera; the circovirus and cyclovirus. It infects birds, mammals, aquatic animals and invertebrates $[3,4]$. Hitherto, the virus called gyrovirus (chicken anemia virus) was classified under the family circoviridae, this virus is now classified in the distinct family called Anelloviridae which has a propensity to infect humans also $[3,5,6]$.

The genus circovirus consists viruses of freshwater fish, and catfish, mammals and birds [7-9]. It includes Barbel circovirus, Bat associated circovirus 1-9, Beak and feather disease virus, Beaked whale circovirus, Black-headed python circovirus, Canary circovirus, Canine circovirus, Chimpanzee associated circovirus 1, Duck circovirus, European catfish circovirus, Finch circovirus, Goose circovirus, Gull circovirus, Human associated circovirus 1, Mink circovirus, Pigeon circovirus, Porcine circovirus 1-3, Raven circovirus, Starling circovirus, Swan circovirus and Zebra finch circovirus [4]. Among those viral species, porcine circovirus (PCV) has become known by its economic impact in the piggery industry. As wholesome pig production is crucial to satisfy the pork and other pig product demands in the world, the health of this animal should be sustained satisfactorily [1012].

PCVs are divided into three sub-species: PCV1, PCV2 and PCV3. PCV1 and PCV2 were found in the 1970s and 1990s, respectively. The presence of porcine circovirus 2 before 1974 and 1998 (official detection of PCV2) was confirmed by various retrospective studies $[13,14]$. But clinical severity of the diseases gives the impression to have 


\section{Open Access Journal of Veterinary Science \& Research}

increased dramatically since 1997 . While another type called PCV3 was first noted in 2015 in North Carolina in the USA form pigs with characteristics of cardiac and multisystemic inflammation with metagenomic sequencing. Undoubtedly, PCV1 doesn't cause any remarkable ailment in pigs [15]. However, PCV3, similar to PCV2, is reported to be associated with several swine diseases, including porcine dermatitis and nephropathy syndrome (PDNS) and reproductive failure [16].

PCV2 has been recognized as one of the main agents accountable for PCV-associated disease (PCVAD) which has caused immerses economic losses to the global pig industry $[17,18]$. The complete genome sequence of PCV2 ranges from 1766 or1768 bp and encodes at least for 11 predicted open reading frames (ORFs) $[19,20]$. Henceforth, ORF1 (encodes for rep and rep'), ORF2 (encodes for cap protein) and ORF3 responsible for apoptotic pathway in invitro and viral pathogenesis in vivo and ORF4 have been studied well. Furthermore, ORF5 and ORF6 might have an inhibitory role against host immune surveillance and protein may be involved in caspases regulation and the expression of multiple cytokines respectively, [21-23].

PCVs are very common in domestic pigs as well as in wild swine population. However, PCVs have been occasionally isolated from non-porcine animals, including cattle, goats, wild chamois, and roe deers, mice, raccoon dogs, minks, foxes, and raccoon dogs, flies, mosquitoes, and ticks, and shellfish [24-26], Pigs are ordinarily the natural reservoirs of the virus. In this mini review, a snap shot of the historical aspects of porcine circovirus with emphasis on type 2 and its host preferences will be spotlighted. Which might enable some beginners and experts to have a quick over view in this groups of viruses?

\section{Historical outlooks}

PCV was first discovered in Germany in 1974 [27]. But in the 1990s a new circovirus was emerged that it was different from the PCV reserved as cell culture contaminant. In Canada, the first known outbreak of PCV has been reported. This virus was initially termed like papovavirus, and picornavirus-like come to be called post weaning multisystemic wasting syndrome. Following this, there also new report that john harding has also stated similar disease syndromes in pigs kept intensively, in Saskatchewan, Canada. Ensuing investigation of samples submitted to WCVM in 1995, Lori Hassard reported smaller dense particles, 19-19 $\mathrm{nm}$ that lacked the hallow appearance of parvo viruses in electro micrographs [28]. After 2 years of trail, Lori Hassard isolated a circovirus from PMWS case samples submitted which was different from viruses found in Germany $[28,29]$.
Afterwards of the year 1997, the virus was reported in Canada, United States and Europe [30-32]. This virus isolates have shared less than $80 \%$ of sequence identity than the previous cell culture contaminant virus. There after the nonpathogenic one come to be named as Porcine Circoviruses type 1 and the one that associated with disease called as Porcine Circoviruses type 2 [33]. However, retrospective studies of coronaviruses revealed that the virus has been found earlier than 1990s in Europe and America [13,14].

While in Asia, PCV2 infection was first stated in China in 2000. To date the phylogenetic analyses of the complete genome and ORF2 region of PCV2 isolates worldwide have shown that PCV2 could be divided into eight distinct genotypes. These have been named PCV2a, PCV2b, PCV2c, PCV2d, PCV2e, PCV2f, PCV2g and PCV2h, which are still circulating in the world [34-36]. Some studies in china indicated that some of this genotypes share more than $78.7 \%$ of sequence identity [37]. Up to 2003 the PCV2a was a main strain that infects the pigs worldwide. However, since then, PCV2b becomes the dominant genotype in the porcine population in America, Europe and Asian (albeit now days the PCV2d become more prevalent in Asia and Europe) countries. The newly identified sub-genotype $[35,37,38]$.

\section{The Disease In Swine Population}

Porcine circovirus (PCV) type 2 causes' porcine circovirus associated diseases. PCVAD caused by PCV2 affects multiple systems of the animals and is the etiological agent of postweaning multi-systemic wasting syndrome [39-41]. Drastic wasting and lymphadenopathy are the characteristic signs of PMWS. Lymphoid system, respiratory system, nervous system, digestive system, urinary system, reproductive system, integumentary system, cardiovascular system and endocrine system of pigs are involved in the infection. Currently, the diseases caused by PCV2 has resulted poor growth, increased mortality, and weight loss progressing to emaciation in pigs between the ages of 5 and 18 weeks and the diseases become complicated while if there is coinfection with other viral and bacterial diseases[29,42-47]. Thereby it affects the pig production worldwide.

\section{PCV2 Infection In Different Animal Species}

PCV2 is known to infect both domestic and feral swine. However, in now days, the virus is detected from many other mammals and insects. It could infect mice, calves, minks, canines and goats [24-26].

\section{Raccoon dogs and mink}

The prevalence of PCV2 stains in canine has also reported in china. They documented that PCV2 isolates were identified from raccoon dogs with the symptom of reproductive failure. 


\section{Open Access Journal of Veterinary Science \& Research}

PCV2 affected raccoon dogs also show inappetence, lethargy, depression, abortion, and sterility [24,48-50].

\section{Calves}

In recent times PCV2 infects caves and causes some haemorrhagic diseases. PCV2 has been reported form beef in USA. On the other hand PCV3 has been detected in zenotransplanted organs (heart) of baboon and later to all other organs of it [51]. But the recent report from Xaver Sidler in Switzerland has indicated that no PCV2-specific humoral response has been measured in cattle after experimental infection with PCV2 virus genome. On the other hand, PCV2 genome was found from dead piglets in china [11,52].

\section{Goats}

Goats are another mammal which PCV2 genome has been detected. In china $6.12 \%$ of prevalence of PCVd has been reported [53-55]. Furthermore insects like mosquitoes can potentially carry and act as mechanical vectors for the transmission of PCV in pig farms [52]. Thus form those investigations it supports the inkling of cross species transmission of PCV2.

\section{Conclusion}

Porcine circoviruses is the cause of porcine circovirus associated diseases that it causes huge economic loss in the piggery industry. According to retrospective studies, PCV2 has been there circulating before its official detection in the first outbreak in Canada. Since from it official detection, various phylogeny studies supported for the immergence of new Porcine circoviruses variants and genotypes. The virus is almost ubiquitous in the environment and endemic in almost all parts of the countries mainly which kept pigs for pork and those import different products of pork for consumption. It has been also isolated in non-porcine species that it intently gives the clue that it inhibits calves, goats, canines and mice. Some insects like mosquitoes are also the potential carriers of PCV2 and hence that proper control of the likely carrier vectors should be noted together with the need of efficient vaccine against the Porcine circoviruses type 2.

\section{References}

1. (2019) Molecular and Cellular Biology of Viruses, $1^{\text {st }}$ (Edn.),. Anticancer Res 39(9): 5227.

2. Iwami S, Sato K, De Boer RJ, Aihara K, Miura T, et al. (2012) Identifying viral parameters from in vitro cell cultures. Front Microbiol 3: 319.

3. Rosario K, Breitbart M, Harrach B, Segalés J, Delwart E, et al. (2017) Revisiting the taxonomy of the family
Circoviridae: establishment of the genus Cyclovirus and removal of the genus Gyrovirus. Arch Virol 162(5): $1447-1463$.

4. Breitbart M, Delwart E, Rosario K, Segalés J, Varsani A, et al. (2017) ICTV Virus Taxonomy Profile: Circoviridae. J Gen Virol 98(8): 1997-1998.

5. Schat KA (2009) Chicken anemia virus. Curr Top Microbiol Immunol 331: 151-183.

6. Smuts HE (2014) Novel Gyroviruses, including Chicken Anaemia Virus, in Clinical and Chicken Samples from South Africa. Adv Virol 2014: 321284.

7. Lőrincz M, Dán A, Láng M, Csaba G, Tóth AG, et al. (2012) Novel circovirus in European catfish (Silurus glanis). Arch Virol 157(6): 1173-1176.

8. Lorincz M, Cságola A, Farkas SL, Székely C, Tuboly T (2011) First detection and analysis of a fish circovirus. J Gen Virol 92(8): 1817-1821.

9. Lorincz M, Cságola A, Biksi I, Szeredi L, Dán A, et al. (2010) Detection of porcine circovirus in rodents - short communication. Acta Vet Hung 58(2): 265-268.

10. Afolabi KO, Benson C Iweriebor, Anthony I Okoh, Larry C Obi (2017) Global Status of Porcine circovirus Type 2 and Its Associated Diseases in Sub-Saharan Africa. Adv Virol 2017: 6807964.

11. Kekarainen T, Segalés J (2015) Porcine circovirus 2 immunology and viral evolution. Porcine Health Manag 1: 17 .

12. McGlone JJ (2013) The Future of Pork Production in the World: Towards Sustainable, Welfare-Positive Systems. Animals (Basel) 3(2): 401-415.

13. Labarque GG, Nauwynck HJ, Mesu AP, Pensaert MB (2000) Seroprevalence of porcine circovirus types 1 and 2 in the Belgian pig population. Vet Q 22(4): 234-236.

14. Magar R, Muller P, Larochelle R (2000) Retrospective serological survey of antibodies to porcine circovirus type 1 and type 2. Can J Vet Res 64(3): 184-186.

15. Tischer I, Mields W, Wolff D, Vagt M, Griem W, et al. (1986) Studies on epidemiology and pathogenicity of porcine circovirus. Arch Virol 91(3-4): 271-276.

16. Jiang H, Wang D, Wang J, Zhu S, She R, et al. (2019) Induction of Porcine Dermatitis and Nephropathy Syndrome in Piglets by Infection with Porcine Circovirus Type 3. J Virol, 2019. 93(4): e02045-e02118. 


\section{Open Access Journal of Veterinary Science \& Research}

17. Kim HH, Park SI, Hyun BH, Park SJ, Jeong YJ, et al. (2009) Genetic diversity of porcine circovirus type 2 in Korean pigs with postweaning multisystemic wasting syndrome during 2005-2007. J Vet Med Sci 71(3): 349-353.

18. Song T, Hao J, Zhang R, Tang M, Li W, et al. (2019) First detection and phylogenetic analysis of porcine circovirus type 2 in raccoon dogs. BMC Vet Res 15(1): 107.

19. Guo LJ, Lu YH, Wei YW, Huang LP, Liu CM, et al. (2010) Porcine circovirus type 2 (PCV2): genetic variation and newly emerging genotypes in China. Virol J 7: 273.

20. He J, Cao J, Zhou N, Jin Y, et al. (2013) Identification and functional analysis of the novel ORF4 protein encoded by porcine circovirus type 2. J Virol 87(3): 1420-1429.

21. Choi CY, Choi YC, Park IB, Lee CH, Kang SJ, et al. (2018) The ORF5 protein of porcine circovirus type 2 enhances viral replication by dampening type I interferon expression in porcine epithelial cells. Vet Microbiol 226: 50-58.

22. Li D, Wang J, Xu S, Cai S, Ao C, et al. (2018) Identification and functional analysis of the novel ORF6 protein of porcine circovirus type 2 in vitro. Vet Res Commun 42(1): 1-10.

23. Lv QZ, Guo KK, Zhang YM (2014) Current understanding of genomic DNA of porcine circovirus type 2. Virus Genes 49(1): 1-10.

24. Zhai SL, Lu SS, Wei WK, Lv DH, Wen XH, et al. (2019) Reservoirs of Porcine Circoviruses: A Mini Review. Front Vet Sci 6: 319.

25. Nayar GP, Hamel AL, Lin L, Sachvie C, et al. (1999) Evidence for circovirus in cattle with respiratory disease and from aborted bovine fetuses. Can Vet J 40(4): 277278.

26. Pinheiro AL, Bulos LH, Onofre TS, de Paula Gabardo M, de Carvalho OV, et al. (2013) Verification of natural infection of peridomestic rodents by PCV2 on commercial swine farms. Res Vet Sci 94(3): 764-768.

27. Tischer I, Rasch R, Tochtermann G (1974) Characterization of papovavirus-and picornavirus-like particles in permanent pig kidney cell lines. Zentralbl Bakteriol Orig A 226(2): 153-167.

28. Ellis J (2014) Porcine circovirus: a historical perspective. Vet Pathol 51(2): 315-327.

29. Ellis J, Hassard L, Clark E, Harding J, Allan G, et al. (1998) Isolation of circovirus from lesions of pigs with postweaning multisystemic wasting syndrome. Can Vet J 39(1): 44-51.
30. Allan GM, McNeilly F, Kennedy S, Daft B, Clarke EG, et al. (1998) Isolation of porcine circovirus-like viruses from pigs with a wasting disease in the USA and Europe. J Vet Diagn Invest 10(1): 3-10.

31. Cheung AK, Lager KM, Kohutyuk OI, Vincent AL, Henry SC, et al. (2007) Detection of two porcine circovirus type 2 genotypic groups in United States swine herds. Arch Virol 152(5): 1035-1044.

32. Grierson SS, King DP, Wellenberg GJ, Banks M (2004) Genome sequence analysis of 10 Dutch porcine circovirus type 2 (PCV-2) isolates from a PMWS case-control study. Res Vet Sci 77(3): 265-268.

33. Meehan BM, McNeilly F, Todd D, Kennedy S, Jewhurst VA, et al. (1998) Characterization of novel circovirus DNAs associated with wasting syndromes in pigs. J Gen Virol 79(9): 2171-2179.

34. Bao F, Mi S, Luo Q, Guo H, Tu C, et al., (2018) Retrospective study of porcine circovirus type 2 infection reveals a novel genotype PCV2f. Transbound Emerg Dis 65(2): 432-440.

35. Wen L, Guo X, Yang H (2005) Genotyping of porcine circovirus type 2 from a variety of clinical conditions in China. Vet Microbiol 110(1-2): 141-146.

36. Franzo G, Segales J (2018) Porcine circovirus 2 (PCV2) genotype update and proposal of a new genotyping methodology. PLoS One 13(12): e0208585.

37. Liu J, Wei C, Dai A, Lin Z, Fan K, et al. (2018) Detection of PCV2e strains in Southeast China. Peer J 6: e4476.

38. Xiao CT, Halbur PG, Opriessnig T (2012) Complete genome sequence of a novel porcine circovirus type $2 \mathrm{~b}$ variant present in cases of vaccine failures in the United States. J Virol 86(22): 12469.

39. Chae C (2005) A review of porcine circovirus 2-associated syndromes and diseases. Vet J 169(3): 326-36.

40. Ge X, Fang Guo, Xin Yang, Hanchun (2012) Porcine circovirus type 2 and its associated diseases in China. Virus Res 164(1-2): 100-106.

41. Segalés J, Allan GM, Domingo M (2005) Porcine circovirus diseases. Anim Health Res Rev 6(2): 119-142.

42. Opriessnig T, Langohr I (2013) Current state of knowledge on porcine circovirus type 2-associated lesions. Vet Pathol 50(1): 23-38.

43. Huang YY, Walther I, Martinson SA, López A, Yason C, et al. (2008) Porcine circovirus 2 inclusion bodies in 


\section{Open Access Journal of Veterinary Science \& Research}

pulmonary and renal epithelial cells. Vet Pathol 45(5): 640-644.

44. Rosell C, Segalés J, Plana-Durán J, Balasch M, Rodríguez-Arrioja GM, et al. (1999) Pathological, immunohistochemical, and in-situ hybridization studies of natural cases of postweaning multisystemic wasting syndrome (PMWS) in pigs. J Comp Pathol 120(1): 59-78.

45. Opriessnig T, Meng XJ, Halbur PG (2007) Porcine circovirus type 2 associated disease: update on current terminology, clinical manifestations, pathogenesis, diagnosis, and intervention strategies. J Vet Diagn Invest 19(6): 591-615.

46. Ouyang T, Zhang X, Liu X, Ren L (2019) Co-Infection of Swine with Porcine Circovirus Type 2 and Other Swine Viruses. Viruses 11(2): E185.

47. Harding JC (2004) The clinical expression and emergence of porcine circovirus 2. Vet Microbiol 98(2): 131-135.

48. Wang GS, Sun N, Tian FL, Wen YJ, Xu C, et al. (2016) Genetic analysis of porcine circovirus type 2 from dead minks. J Gen Virol 97(9): 2316-2322.

49. Wang L, Gong W, Fu H, Li M, Zhang Y, et al. (2018) Hepatitis E virus detected from Chinese laboratory ferrets and farmed mink. Transbound Emerg Dis 65(1): e219-e223.

50. de Castro AM, Taís F Cruz, Katarina B Yamada, Priscilla F Gerber, Michelle P Gabardo, et al. (2015) Preliminary evidence of age-dependent clinical signs associated with porcine circovirus $2 \mathrm{~b}$ in experimentally infected $\mathrm{CH} 3$ / Rockefeller mice. Res Vet Sci 103: 70-72.

51. Denner J, Mankertz A (2017) Porcine Circoviruses and Xenotransplantation. Viruses, 2017. 9(4): 83.

52. Zhai SL, Zhou X, Lin T, Zhang H, Wen XH, et al. (2017) Reappearance of buffalo-origin-like porcine circovirus type 2 strains in swine herds in southern China. New Microbes New Infect 17: 98-100.

53. Wang X, Wenliang Li, Xianglan Xu, Wei Wang, Kongwang He, et al. (2018) Phylogenetic analysis of two goat-origin PCV2 isolates in China. Gene 651: 57-61.

54. Palinski R, Piñeyro P, Shang P, Yuan F, Guo R, et al. (2016) A Novel Porcine Circovirus Distantly Related to Known Circoviruses Is Associated with Porcine Dermatitis and Nephropathy Syndrome and Reproductive Failure. Journal of virology 91(1): e01879-e01916.

55. Yang X, Hou L, Ye J, He Q, Cao S (2012) Detection of porcine circovirus type 2 (PCV2) in mosquitoes from pig farms by PCR. Pak Vet J 32(1): 134-135. 